\author{
A. Sotnikov, M. Yasechko, A. Tantsiura, A. Ochkurenko, D. Maksiuta \\ Ivan Kozhedub Kharkiv National Air Force University, Kharkiv, Ukraine
}

\title{
THE EXISTING METHODS AND PROTECTION PRODUCTS ANALYSIS OF RADIO ELECTRONIC EQUIPMENT FROM THE POWERED PULMONARY ELECTROMAGNETIC RADIATION EFFECT OF ULTRASONIC SHORT-TERM PERMEABILITY
}

\begin{abstract}
The possibilities analysis of the implementing protection radio electronic means from the powerful pulsed electromagnetic radiation by known methods and existing devices has been carried out. It was determined that at the operation stage of the radio-electronic means the main method of protection is shielding. But the presence of technological openings, cable entry channels, defects in enclosures makes it impossible to protect radio electronic devices from powerful pulsed electromagnetic radiation of ultra short duration by this method. It has been pointed out the need to search for new technologies that will reduce or completely eliminate the penetration of electromagnetic radiation into the cascades of radio-electronic means. The concept of the radio-electronic protection means at their use stage is formulated on the basis of nature-like absorption technologies, reflection and removal of the powerful pulsed electro absorbing and locking properties of the protective equipment. Nature-like technologies have the advantage of an instantaneous response of the state of the electronic subsystem to the effects of electromagnetic radiation and, accordingly, an instantaneous change in the electro physical properties of the solid-state ionized air environment. Thus, an instant change occurs in the reflective, absorbing and locking properties of the protective equipment. Also, such technologies retain their performance throughout the entire electronic means life cycle and have the ability to withstand pulsed overload.
\end{abstract}

Keywords: methods of protection from exposure to powerful electromagnetic radiation; radio-electronic means; solidstate plasma medium; gaseous plasma medium; radioisotope technology.

\section{Introduction}

It is known that electromagnetic radiation (EMR) of the ultra-short duration (USD) is capable of disabling modern radio electronic facilities (REF) by affecting the sensitive element base. Considering that modern power generation facilities, communications equipment, control systems, computer and telecommunication networks, life support equipment contain radio-electronic equipment (REF), the ensuring sustainability task of a radio-electronic device to the impact of a powerful pulsed electromagnetic pulse becomes urgent.

The operation of radio electronic, electro technical and electrical equipment, providing important strategic military-technical objects, is also associated with the implementation of the measures to protect them from the destabilizing effect of the powerful EMR USD. The REF protection implementation for various purposes is based on the use of appropriate methods and protection devices, depending on the parameters of the EMR.

The available domestic and foreign literature analysis indicates the great interest of scientists to study the generating powerful electromagnetic radiation processes EMR [1-4], the use of powerful generators EMR, including the one to influence the element base of the REF. The results that characterize the state of recent advances in the protection of the REF from the powerful EMR are presented in [5-14]. Also, many works are devoted to traditional methods and means of protecting radio electronic devices against the effects of microwave radiation [1-3, 15-17]. Recently, there have been publications devoted to the use of radioisotope technologies for the radio electronic devices protection against the effects of powerful electromagnetic radiation, which are nature-like [18-20]. The nature of these technologies is associated with the use of reflecting and absorbing properties of plasma, which is the most common state of matter. It is also associated with the use of the lightning properties, as a discharge in the air, which, in the first approximation, can be used to create a highly conductive state of air in holes, in the slots of shield cases to protect against the powerful EMR through breakdown and further removal of the EMR energy.

According to [21, 22], there are distinguished methods to protect REF from exposure to EMR, whose classification is shown in Fig. 1.

Let us consider the possibility of applying these methods to determine the protection concept of a radio electronic system depending on the stage of the life cycle.

The purpose of the article is to analyses the capabilities of the known methods, means and devices for the protection of radio electronic devices against the effects of a pulsed powerful electromagnetic pulse and to determine the directions for their further development.

\section{Main material}

The general principle of the structural protection method consists in shielding the equipment, choosing the optimal grounding schemes for each specific case. The most common ways of practical implementation of the structural method of protecting a REF from the effects of electromagnetic radiation are the use of electromagnetic shields located around the REF and grounding devices, which divert electrical disturbances and currents to earth.

Shielding [22-25] is understood to mean the localization of an electromagnetic field in a certain space by limiting its propagation in all possible ways. The most common type of screen is a metallic closed shell that prevents the electromagnetic field from entering the electromagnetic radiation energy. In addition to its main functional purpose, the screen acts as an element of the supporting structure 
and, in addition to weakening and absorbing the energy of the electromagnetic field, must have the necessary mechanical strength, rigidity, ease of fixing in the overall design of the device, have minimum dimensions and weight. Therefore, the choice of screen material is determined on the one hand by ensuring the effectiveness of protection, and on the other hand by the production conditions of manufacture (if the screen is also used as a carrier element, then the requirements determined by this circumstance are also taken into account).

From a physical point of view, the screening is as follows. EMR is partially reflected from the screen outer surface and partially absorbed by the screen material. Theoretical and experimental studies [22 - 25] showed that the shape of the screen has little effect on its effectiveness. The main factor determining the quality of the screen is the radio physical properties of the material and structural features. This makes it possible to use the simplest screen form when calculating screen efficiency: sphere, cylinder, plane-parallel sheet, etc. The effectiveness of shielding is the presence of technological holes in the screen (input-output devices, ventilation), and in the shielded rooms - life support devices that connect the premises with the external environment.

When designing electromagnetic shields, it is generally necessary to take into account that at relatively low frequencies it is more difficult to ensure effective shielding of the magnetic field component, while shielding the electric component presents no particular difficulty even when using perforated or mesh screens.

A special place among the materials used for shielding static and quasi static magnetic fields is occupied by amorphous ferro magnets. The magnetic screen is made of Permalloy-type alloys containing $20 \%$ of $\mathrm{Fe}$ atoms and $80 \%$ of $\mathrm{Ni}$ atoms. High magnetic properties are achieved by the complex and expensive heat treatment. The magnetic properties of amorphous alloys are quite high, which allow them to be used as a shielding material. Shields of amorphous alloys are not sensitive to shock. They initially have high magnetic permeability, which retains its level to frequencies of the order of hundreds of megahertz. For example, Metschild fabric from an amorphous Fe40Ni40P14B6 alloy in the form of a tape $1.5 \mathrm{~mm}$ wide and 58 microns thick was used to shield cables in equipment installed on board a Voyager class spaceship. The research results showed that the protective ability of such a fabric reaches $11 \mathrm{~dB}$ at a magnetic field strength of $40 \mathrm{~A} / \mathrm{m}$ and $24 \mathrm{~dB}$ at a field strength of $200 \mathrm{~A} / \mathrm{m}$ and a frequency of $60 \mathrm{~Hz}$. These values exceed the characteristics of similar screens made of Permalloy-type alloys in 1.5-2 times and do not change after mechanical stress.

Today it has become possible to create screens of amorphous alloys with shielding coefficients up to 60
Methods of protection of REF from the influence of powerful EMR
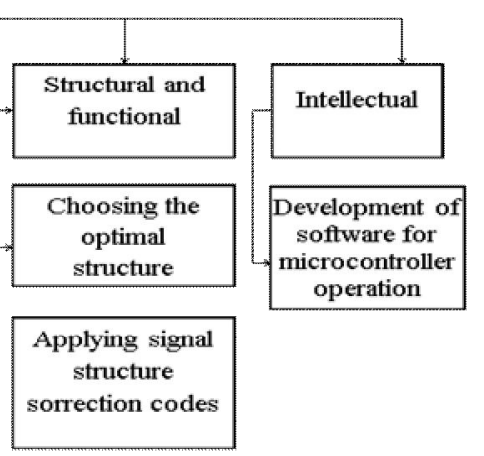

The use of elements of optoelectronics

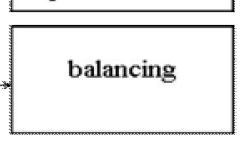

Selection of the optimal structure operation algorithm

Selection of the optimal

modulation and

coding system

g. 1. The main methods of protecting REF from the effects of powerful electromagnetic radiation

$\mathrm{dB}$ for industrial interference and radio frequency range. Magnetic screens for quasi static fields (Earth's magnetic field) have also been developed from amorphous ferro magnets. Now it is possible to use an amorphous ferromagnetic micro wire for magnetic shielding of a small volume.

In addition, in [26], the original manufacturing techniques of the knitted screening fabric with a smooth and relief surface and methods for measuring their characteristics are given.

In [27], a method was proposed for protecting onboard digital computers from the effects of EMR, in which a method of shielding electrical equipment using metal grids and continuous thin-walled metal sheets is also used. The disadvantages of this method are that when it is used, there are big problems with ensuring effective shielding of objects through the technological difficulties of manufacturing screens that have no heterogeneity and defects (in particular, the presence of inputs), which makes it impossible to completely shield electrical circuits and devices.

In other proposed screens, the disadvantages are the presence of components (welding, bolted connections), doors, gaskets, openings, cable glands and mechanical effects on the screen.

Radar absorbing coatings (RAC) and materials are widely used to create screens. Despite the wide range of RACs developed at present, we will analyses their characteristics with respect to the possibility of using them to protect the radio electronic equipment (REE) from the pulsed electromagnetic radiation (EMR).

Radio absorbing coatings and materials (RAM) as protective materials REF from the exposure to electromagnetic radiation EMR.

RAC and RAM are designed to reduce the reflection of electromagnetic radiation inside the shielding objects, as well as to ensure their electrical sealing [28 29]. 
The following main types of RAC are known, the classification of which is shown in Fig. 2

The coatings are flatlayered in which a decrease in the incident radiation is achieved by the mutual attenuation of waves reflected from the object's surface and the coating surface. Falling EMR is repeatedly reflected from the separation of two "coating-object" media and is partially absorbed by the coating substance. If the coverage is perfect, then the total field in the direction of the source of the incident wave is zero. An example of such coatings is the quarter-wave RAC and RAM

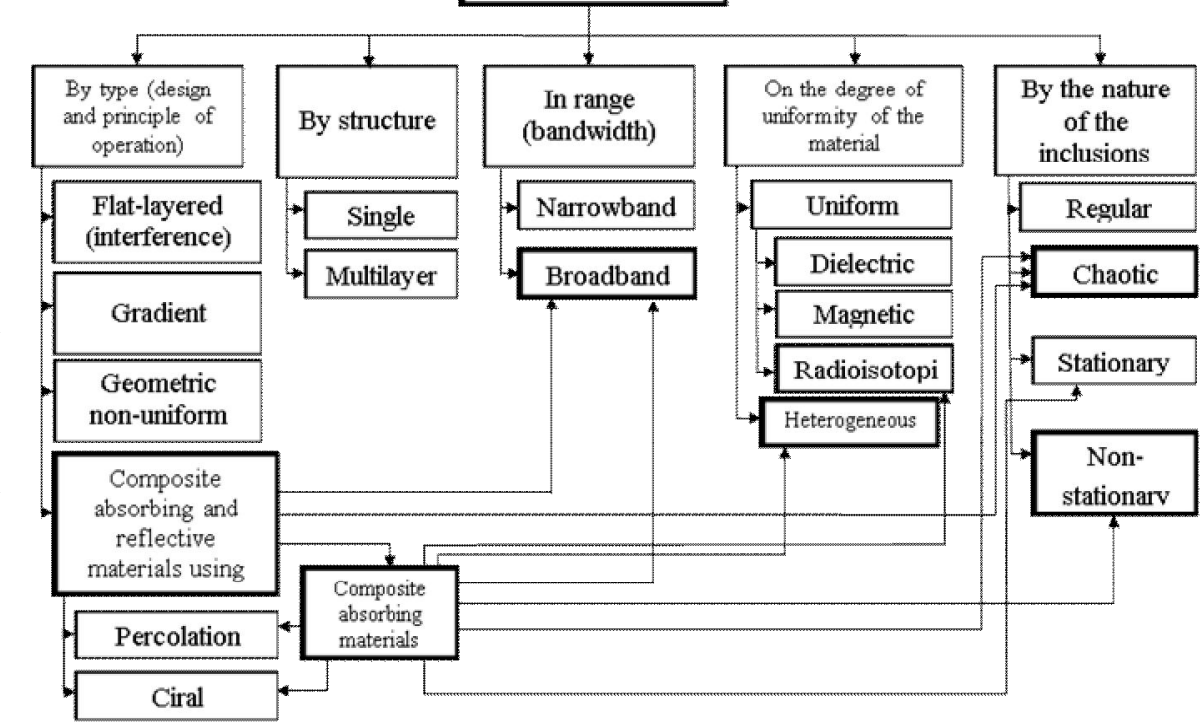

Fig. 2. Classification RAC and RAM

absorber EMR. The disadvantages of such coatings are their narrow band and high dependence of the reflection coefficient on the angle of the incidence.

The expansion of the working strip can be achieved as a result of a multi-layer structures use with a gradual change in the characteristics of the layers. If the number of layers of the multilayered stepped RAC is unlimited increased (in practice it's up to 10), then such a flat layer structure will turn into a gradient type coating.

For the most effective absorption of microwave radiation, it is better to use the coatings and materials with high dielectric and (or) magnetic permeability. The main physical properties of materials (dielectrics, ferro electrics, metals and their oxides, semiconductors, ferrites), which can be used for use in creating EMR absorbing structures, are given in [30 - 31].

Gradient type coatings have low reflective properties in a wide frequency band. However, they are bulky and the most difficult from the point of view of practical implementation, which is a disadvantage. Geometrically in-homogeneous RAM may have a different shape: sawlike, cone-like, pyramidal. In gradient coatings the coordination with free space is due to the gradual changes in the properties of the absorbing medium based on the use of the constant parameters layers set. The advantages of coatings of this type include a wide working band with a low reflection coefficient. The disadvantages are their sizes, which significantly exceed the sizes of planar RAC and RAM.

The existing RAM by the mechanism of absorption can be divided into two classes:

1. Dielectric materials with low dielectric constant and high absorption level of electromagnetic energy due to electrical conductivity.

2. Ferromagnetic materials that provide absorption of electromagnetic radiation due to magnetic reversal losses.

The most effective ferromagnetic materials with magnetic losses. However, it should be noted that despite the great achievements in the field of creating spe- cial absorbing materials based on ferrite, ceramics and ferrite compounds, it is still not possible to manufacture an effective absorber of electromagnetic radiation EMR in a fairly wide wavelength range at different angles of incidence. Thus, the reflective R of the NZ-31, NZ-41 NZ-51 (Eccosorb) materials as a function of frequency is shown in [32], showing that the reflection ability of these coatings, which are $5 \ldots 8 \mathrm{~mm}$ thick, is $20 \mathrm{~dB}$ (that is, no more than $1 \%$ of the incident energy is reflected) is stored only in the frequency band $=250 \ldots 400 \mathrm{MHz}$ To extend the frequency range using multi-layer coatings. However, the high proportion of ferromagnetic materials makes it unacceptable to use them on the flying aircraft (FA). But in work [33] it is noted that Russian specialists managed to create the world's first protective material of small specific gravity (only $0.2 \mathrm{~kg} / \mathrm{m}^{2}$ ) and with high absorbing properties. The material protects them from electromagnetic radiation EMR in the range from $0.5 \mathrm{GHz}$ to $50 \mathrm{GHz}$, and also reduces the level of electromagnetic exposure by up to $10-30 \mathrm{~dB}$ (radiation reflected from the material) and up to $100 \mathrm{~dB}$ (radiation passed for the material).

Ferrite fabric has the highest flexibility, which allows it to cover almost everything. The material can be used in the temperature range from -50 to +110 degrees Celsius. At present, the production of linen size 500 by 500 millimeters.

To expand the frequency range while ensuring high efficiency of absorption of electromagnetic waves, composite materials with various kinds of inclusions and the so-called artificial media [34 - 45], whose work is based on the principle of scattering and absorption of electromagnetic radiation EMR at resonant frequencies determined by the size of inclusions. So, to create effective RACs, the possibility of using chiral and percolation materials related to the composite materials [46 47] is being investigated.

Chiral environment is an isotropic dielectric, in which mirror-asymmetric elements are randomly distributed. Percolation materials use disordered mixtures of high and low conductive particles. At a certain criti- 
cal concentration of highly conductive particles, which is called the percolation threshold, a metal-insulator transition is observed in such an environment [48].

Percolation environment have abnormally high dielectric constant. Conductivity is characterized by anomalous non linearity. By changing the conductivity, size and concentration of conductive inclusions, it is possible to vary the capacitive and inductive properties of percolation clusters and, therefore, create materials with the necessary electro-physical properties, including those that have low-reflective properties. An example of coatings made from such materials are coatings that use a powder consisting of miniature ceramic medium coated with metal $[42,46]$. The diameter of the ceramic medium is in the range of $5 \ldots 75$ microns. When using such powder as an impurity to the paint, its cost lies within the range of $\$ 1-2$ per square foot (1 foot $=$ $0.3048 \mathrm{~m})$. At the same time, it increases the paint weight by just 0.05 pounds per square foot $(1$ pound $=$ $0.48 \mathrm{~kg}$ ) to the weight of the paint. It is argued that, based on the properties of such a powder, coatings can be created to absorb electromagnetic radiation in the range $1 \ldots 100 \mathrm{GHz}$.

Magnetic granular materials are considered to be promising. They represent a structural composite in which ferromagnetic particles with a crystal structure are placed in a dielectric matrix [49]. One of the advantages of such materials is the ability to easily control their parameters by changing the concentration of the component introduced into the composite. In this case, there is a real possibility of creating an absorbing material with a low reflection coefficient of high-frequency electromagnetic radiation [50]. Dielectric matrices with ferromagnetic particles included in them are widely used as absorbers [49], as well as as fillers for wave guides and resonators in various non-reciprocal microwave engineering devices. In [51 - 52], it was shown that in composites based on hexagonal ferrites (HF) and polymer bonding, the absorption of electromagnetic radiation EMR occurs due to the natural ferromagnetic resonance. Such materials are promising to use in the frequency range $2.6 \mathrm{GHz}$.

The results of the conducted research allow to conclude that RAC and RAM models based on the modified materials have a high degree of a EMR absorption.

High-temperature superconductors (HTSC), as protective materials REF from the effects of electromagnetic radiation EMR.

According to the results of [28 - 29], one of the ways to protect the REF from the effects of a powerful EMR USD through the antenna mechanism is protection based on strip-film structures, made out of hightemperature superconductors. Protection devices operate on the basis of the phase transitions use in the transmission lines of HTSCs, which use the transition from the superconducting state to the normally conducting state.

The widespread practical use of HTSC in microwave technology is primarily limited by their nonlinear properties and the need to use liquid nitrogen.

In [53], a device was considered to protect the receiver (Fig. 3), which consists of a ferrite triple-shoulder wave guide Y-circulator 1 , which switches to where the antenna 3 is connected to the input of the first arm 2 of the circulator 1 , the absorbing load 5 is connected to the output of the second arm 4, and the third arm 6 is connected to the receiver 7 . Inside the second arm 4, two parallel plates 8 are installed, made out of a hightemperature superconductor, for example, of the $\mathrm{YBa} 2 \mathrm{Cu} 3 \mathrm{O} 7$ type with a thickness greater than the thickness of the skin layer in this superconductor. The space between the plates 8 , which are adjacent to the walls of the wave guide shoulder 4, is filled with liquid nitrogen 9, coming through the pipes 10 from the cryogenic generator 11 of a closed cycle. The second shoulder 4 in the area of the plates 8 is placed inside the solenoid 12 .

The device for protecting the receiver works as follows. First, the volume between the plates 8 is filled with liquid nitrogen 9, coming through the pipes 10 from the cryogenic generator 11 of a closed cycle.

A closed loop reduces the weight of the cooling system. Under the action of liquid nitrogen 9, the plates 8 become superconducting. When low-power signal carrying information arrives at the antenna 3, the signal, in accordance with the principle of the circulator 1 , enters the other arm 4. Since the plates 8 are made out of HTSCs and are in superconducting states, the information signal is reflected from them and enters the third arm 6 and through it to the receiver 7 . When the antenna receives 3 high-power pulsed EMRs that exceed the power level of the transition of the superconducting plates to the normal state, this radiation enters the arm 4 and destroys the superconductivity of the plates 8, transferring them into a nonsuperconducting (normal) state.

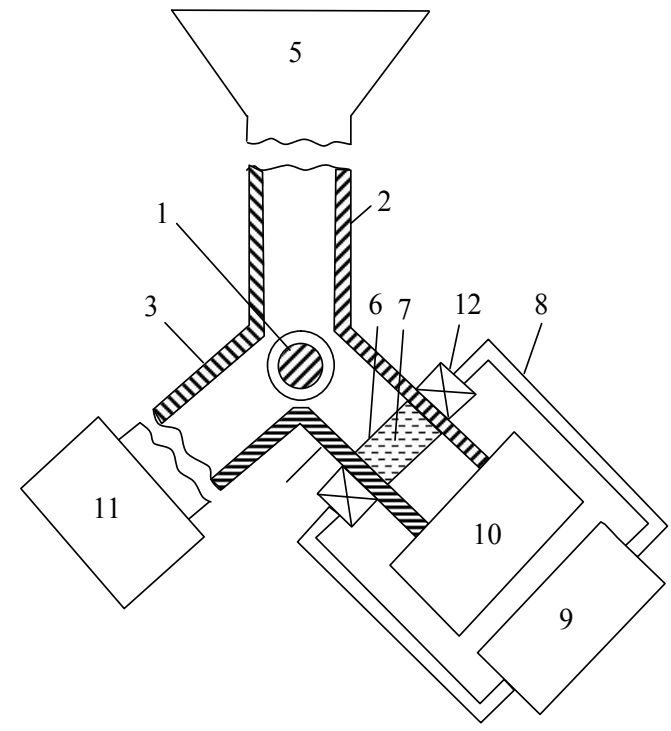

Fig. 3. The receiver protective device

Plates 8 will be transparent for a powerful signal, which along arm 4 enters the absorbing load 5 and does not fall into the third arm. In addition, the plates 8 with destroyed superconductivity will also absorb the power of electromagnetic radiation. Upon the termination of exposure to high-power radiation, the superconductivity of the plates 8 is instantly restored and the receiver 7 again operates in normal mode, receiving an information signal. 
Thus, the receiver is protected automatically when the superconductivity of the plates 8 is destroyed due to the energy of the very powerful radiation itself, and the transition time from the superconducting state to the normal state and vice versa is no more than $10^{-12}$ seconds. Adjustment of the protective power level is made by changing the magnitude of the magnetic field generated by the solenoid 12 .

However, despite the simplicity of the protective device, the physical nature of the transition of the hightemperature superconductor to the normal state, under the influence of the microwave signal, has not yet been fully clarified.

The theoretical estimates show that already at power levels of the order of $10^{-3} \mathrm{~W}$, a process of penetration into the HTSC film of Abrikosov's vortexes formed by a microwave field may occur, and therefore nonlinear effects appear and lower conductivity zones are formed.

This requires solving a number of problems related to the study of the basic properties of HTSC superconductors necessary for the creation of highspeed micro strip lines (MSL) and co planar lines (CPL) of transmission lines.

To implement the practical design of the protective device, it is necessary to conduct additional studies to optimize the design and topology, as well as the analysis of thermal processes at different amplitudes and duration of a parasitic EMR.

Nature-like technologies for creating materials and environmental protection environments.

In works $[1,18-20]$, it was proposed to use nature-like technologies that most satisfy the set of requirements for protection.

The use of nature-like (plasma) technologies introduces a number of new properties to the protection means compared to the conventional means. The most important of these are the instantaneous response of the state of the electronic subsystem, and accordingly, the change in the electrical properties of a solid-state and ionized air that determines the reflecting, absorbing and locking properties of a protective equipment under the influence of a powerful pulsed electromagnetic radiation EMR, performance throughout the life cycle of a REF, and the ability to withstand pulse over voltages .

A number of provisions of the general theory of radio absorbing materials and coatings, the theory of electrodynamics of composite materials, the kinetic theory of plasma, the fundamentals of electrodynamics of radiation and its interaction with matter, the theory of gas and plasma breakdown can be used in the study of individual properties of the plasma protective equipment. However, the analysis of the known scientific results in the study of the electrodynamics plasma medium characteristics showed the presence of a powerful pulsed EMR, a heterogeneous conductivity structure of the screen material due to the radioisotope and hexaferrite elements, the effect of changes in air pressure on the development of breakdown, the occurrence of Langmuir oscillations in the protective screen. This necessitates the development of a powerful pulsed ultra-wide band fields interaction theory with solid-state plasma-like materials and weakly ionized air medium. This will provide an opportunity to evaluate their response to the rate of rise of current and voltage, shielding, reflecting, absorbing and closing characteristics in order to determine the possibility of using plasma technologies to protect the REF electronic device from high-power pulsed electromagnetic radiation EMR without affecting their operation.

\section{Conclusion}

Thus, the methods and means of protection developed to date are not capable of ensuring, by their characteristics, the necessary effectiveness of the radio electronic means protection for the following reasons:

- lack of the perfect screens;

- the inability to create or use sealed screens in relation to EMR;

- the inability of existing limiters to withstand pulsed over voltage under the influence of EMR;

- insufficient speed;

- unacceptable weight and size characteristics.

In addition, the use of protection devices antenna inputs leads to the working signals distortion of the receiving and transmitting paths due to the appearance of a heterogeneity in the antenna-feeder path REF.

Based on the analysis and research of existing methods for protecting REF from the effects of highpower electromagnetic radiation emission technologies EMR USD, nature-like technologies, namely, radioisotope-plasma technology, are considered promising.

Such a technology, according to the preliminary estimates, will ensure compliance with the requirements for the means of protecting the electronic device REF from the impulse EMR of the USD along all possible channels of penetration.

REFERENCES

1. Sotnikov, A. Tarshin, V., Vorobiov, O., Savchenko, V. and Kurtseitov, T. (2017) "Development of radioisotopic-plasma technology for the protection of radio electronic means from powerful electromagnetic radiation", Eastern-European Journal of Enterprise Technologies, Vol. 1, № 5 (85), pp. 16 - 22, DOI: http://doi.org/10.15587/1729-4061.2017.91642

2. Kravchenko, V.I. (2008), Electromagnetic weapons, NTU "KPI", Kharkiv, 185 p.

3. Dyakov, A.F., Kuzhekin, I.P., Maksimov, B.K. and Temnikov, A.G. (2009), Electromagnetic compatibility and lightning protection in the power industry, Publishing House MEI, $455 \mathrm{p}$.

4. Ricketts, L.U., Bridges, J.E. and Mayletta, J. (1979), Electromagnetic impulse and methods of protection, Atomizdat, 328 p.

5. Kravchenko, V.I., Bolotov, E.A. and Letunova, N.I. (1987), Radio-electronic means and powerful electromagnetic interference, Radio and communication, $256 \mathrm{p}$.

6. Myrova, L.O. and Chepizhenko, A.Z. (1988), Ensuring the durability of communication equipment to ionizing and electromagnetic radiation, Radio and communication, $296 \mathrm{p}$

7. Kravchenko, V.I. (1991), Lightning protection of radio electronic means, Radio and communication, $264 \mathrm{p}$. 
8. Dobykin, V.D., Kupriyanov, A.I., Ponomarev, V.G. and Shustov, L.N. (2007), Electronic warfare. Power defeat of radioelectronic systems, University book, $487 \mathrm{p}$.

9. Yasechko, M.N., Dokhov, A.I., Ivanets, M.G. and Teslenko, O.V. (2015), Methods of formation and focusing of electromagnetic radiation to influence radio-electronic means, Disa Plus, $216 \mathrm{p}$.

10. Nayden, E.P., Zhuravlev, V.A. and Itin, V.I. (2004), "Magnetic properties of nanoscale powders of hexaferites", Journal of structural chemistry, Vol. 45, pp. 106-111.

11. Skoblikov, O. and Knyazyev, V. (2012), "Shielding Properties of Conductive Shells Exposed to Electromagnetic Impulse of Lightning", International Conference on Lightning Protection, pp. 1-8.

12. Tajirov, A., Cwhanovskaya, I.V., Barsova, Z.V. and Iluoykha, N.G. (2012), "Chemistry and technology of magnetite and barium-containing composite materials on its basis", European Science and Technology: materials of the II international research and practice conference, Vol. II, pp. 80-87.

13. Fazaeli, R., Eslami-Farsani, R. and Targhagh, H. (2015), "Microwave Absorption Properties of Low Density PolyetheleneCobalt Ferrite Nanocomposite", International Journal of Chemical, Molecular, Nuclear, Materials and Metallurgical Engineering, Vol. 9, No. 12. pp. 1450-1453.

14. Liu, T., Zhou, P. H., Xie, J. L. and Deng, L. J. (2011), "The hierarchical architecture effect on the microwave absorption properties of cobalt composites", Journal of Applied Physics, Vol. 110. pp. 1-4.

15. Brzheitsky, V.O., Isakova, A.V. and Rudakov, V.V. (2005), Engineering and Electrophysics of High Voltages, NTU "KhPI", Tornado, $930 \mathrm{p}$.

16. State standard of Ukraine 2793-94 (1994), Compatibility of technical means of electromagnetic. Resistance to strong electromagnetic interference. Terms, Gosstandart of Ukraine, $24 \mathrm{p}$.

17. Sukhorukov, S.A. (2014), Interference suppression devices of CJSC "EMSOTECH", $72 \mathrm{p}$.

18. Iasechko, M. (2017), "Plasma technologies for the protection of radio electronic means from exposure to high-power electromagnetic radiations with ultra short pulse duration", Proc. of the 1-st Annual Conf., Tallinn: DKLex, pp. 18-21.

19. Sotnikov, A., Iasechko, M. (2017), "Use of plasma technologies for the protection of radioelectronic means from the influence of electromagnetic radiation", Vestnik NTU "KhPI", Series: New solutions in modern technologies. Vol. 53 (1274), pp. $182-187$.

20. Sotnikov, O.M., Yasechko, M.M. and Tarshin V.A. (2017), "Protydiya potuzhnomu elektromahnitnomu vyprominyuvanyu dlya zakhystu radioelektronykh zasobiv" [Countering a powerful electromagnetic radiator to protect radio electronic devices] Systems of information processing. Vol. 9 (135), pp. 76-81.

21. Kovtunenko, O.P., Bogucharsky, V.V., Slyusar, V., Fedorov, P.M. (2006) "Zbroya na netradytsiynykh pryntsypakh diyi (stan, tendentsiyi, pryntsypy diyi ta zakhyst vid neyi)" [Weapon on non-traditional principles of action (state, trends, principles of action and protection against it)], $247 \mathrm{p}$.

22. Balyuk, N.V., Kechiev, L.N., Stepanov, P.V. (2007) "Moshchnyy elektromagnitnyy impul's: vozdeystviye na elektronnyye sredstva i metody zashchity" [A powerful electromagnetic pulse: the impact on electronic means and methods of protection] LLC ITD Group. 478 p.

23. All-Union. meeting (1972) [Protection of communication lines and automation against the influence of external electromagnetic field], Institute of Engineers. wish dear trans. $157 \mathrm{p}$.

24. Prokhorov, A.M. (1992) "Fizicheskaya entsiklopediya" [Physical Encyclopedia], Soviet Encyclopedia. Vol. 3. 672 p.

25. Sivaram, M., Batri, K., Amin Salih, Mohammed and Porkodi V. (2019), "Exploiting the Local Optima in Genetic Algorithm using Tabu Search", Indian Journal of Science and Technology, Volume 12, Issue 1, DOI: http://doi.org/10.17485/ijst/2019/v12i1/139577

26. Bogush, V.A., Borbotko, T.V., Gusinsky, A.V. (2003) "Elektromagnitnyye izlucheniya. Metody i sredstva zashchity" [Electromagnetic radiation. Methods and means of protection] Bestprint. $406 \mathrm{p}$.

27. Mikhailov, V.A. (2009) "Obespecheniye stoykosti bortovykh tsifrovykh vychislitel'nykh mashin k vozdeystviyu sverkhkorotkikh elektromagnitnykh impul'sov" [Ensuring the resistance of on-board digital computers to the effects of ultrashort electromagnetic pulses] Autoref. dis. for degree of candidate tech. sciences. $24 \mathrm{p}$.

28. Anechoic, R.F. (1982) [Chamber Test Facilities] KEENE Corp. 154 p.

29. Alimin, B.F. (1989) "Sovremennyye razrabotki poglotiteley elektromagnitnykh voln i radiopogloshchayushchikh materialov" [Modern developments of electromagnetic wave absorbers and radio absorbing materials] Foreign Radio Electronics. No. 2. pp. $75-82$.

30. Hippel, A.R. (1959) "Dielektriki i ikh primeneniye" [Dielectrics and their application] Energoizdat. 336 p.

31. Rez, I.S, Poplavko, Yu. M. (1989) "Dielektriki. Osnovnyye svoystva i primeneniye v elektronike" [Dielectrics. Basic properties and applications in electronics] Radio and communication. $287 \mathrm{p}$.

32. Wallace, J.L. (1993) "Broadband Magnetic Microwave Absorbers: Fundamental Limitations" IEEE Trans. Magn. Vol.29, №6, Pt 3. pp. 4209-4214.

33. Dhivakar, B., Saravanan, S.V., Sivaram, M. and Krishnan R.A. (2012), "Statistical Score Calculation of Information Retrieval Systems using Data Fusion Technique", Computer Science and Engineering, Vol. 2, Issue 5, pp. 43-45, DOI: http://doi.org/10.5923/i.computer.20120205.01

34. Antonov, A.S., Batenin, V.M. and Vinogradov, A.P. (1990), "Elektrofizicheskiye svoystva perkolyatsionnykh sistem" [Electrophysical properties of percolation systems] IVTAN, $120 \mathrm{p}$.

35. Yemets, Yu. P. (2005), "Effective dielectric constant of three-component composite materials with anisotropic structure", ZhTF, Vol. 75, No. 2, pp. 67-72.

36. Yemets, Yu. P. (2004), "Simulation of the electrophysical characteristics of a dielectric medium with a periodic structure", ZhTF, Vol. 74, No. 12, pp. 1-9.

37. Bliokh, K. Yu. and Bliokh, Yu. P. (2004), "What are left-handed media and how are they interesting?", UFN, Vol. 174, No. 4, pp. 439-447.

38. Veselago, V.G. (1967), "Electrodynamics of substances with simultaneously negative $\varepsilon$ and $\mu$ values", Successes of physical sciences, Vol. 7, No. 92, pp. 517-526.

39. Pendri, I.B. (1976), Phys. Rev. Lett., pp. 764-773. 
40. Perrins, W.T., McKensie, D.R. and McPedran, R.C. (1979), Proc. R. Soc. Lond., Vol. 369, pp. 207-225.

41. Manteufel, R.D. and Todreas, N.E. (1994), Int. J. Neat Mass Transfer. Vol. 37, No. 4, pp. 647-655.

42. Tretyakov, S.A. (1994), "Electrodynamics of complex media: chiral, biisotropic materials, Radioengineering and Electronics, Vol. 39, No. 10. pp. 1455-1470.

43. Tretyakov, S.A. (1994), “Approximate boundary conditions for a thin biisotropic layer”, Radio engineering and electronics Vol. 39, No. 1. pp.184-192.

44. Simovski, C.R., Treyakov, S.A., Sochava, A.A., Sauviac, B., Mariotte, F. and Kharina, T.G. (1997), "Antenna model for conductive omega particles", J. of Electromagnetic Waves Applic., Vol. 11, No 11, pp. 1509-1530.

45. Treyakov, S.A. and Sochava, A.A. (1993), "Eigen waves in uniaxial chiral and omega media", Microwave and Optical Technology Letters, Vol. 6, No. 12, pp. 701-705.

46. Tretyakov, S.A. (1994), "Electrodynamics of complex media: chiral, biisotropic materials", Radioengineering and Electronics, Vol. 39, No. 10, pp. 1455-1470.

47. Antonov, A.S., Batenin, V.M. and Vinogradov, A.P. (1990), Electrophysical properties of percolation systems, IVTAN, 120 p.

48. Vinogradov, A.P. (2001), Electrodynamics of composite materials, Editorial URSS, 208 p.

49. Kazantseva, H.E., Ryvkina, N.G. and Chmutin, I.A. (2003), "Prospective materials for absorbers of electromagnetic waves of the microwave range", Radio engineering and electronics, Vol. 48, No. 2, pp. 196-209.

50. Shneiderman, Ya.A. (1975), "Radio absorbing materials", Foreign Radioelectronics, No. 2, pp. 93-113.

51. Ostrovsky, O.S, Soroka, A.S. and Shmatko, A.A. (1994), "Optimization of broadband non-reflective multilayer coatings, Proceedings of the conference "Microwave Technology and Satellite Reception", pp. 125-127.

52. Buchelnikov, V.D., Bychkov, I.V. and Shavrov, V.G. (1992), "The influence of a magneto-resistant connection on the reflection of an electromagnetic wave from a ferrodielectric", Solid State Physics, Vol. 34, No. 11, pp. 3408-3411.

53. Konyakhin, G.F., Vereshchagin, V.L., Kapuro, I.A. and Sotnikov, O.M. (2010), "Prystriy dlya zakhystu pryymacha" [Device for protecting the receiver], Patent UA №54770.

Received (Надійшла) 18.01.2019

Accepted for publication (Прийнята до друку) 13.03.2019

\section{Анализ существующих методов и устройств защиты радиоэлектронных средств от влияния мощного импульсного электромагнитного излучения ультракороткой длительности}

А. М. Сотников, М. Н. Ясечко, А. Б. Танцюра, А. В. Очкуренко, Д. В. Максюта

Проведен анализ возможностей реализации защиты радиоэлектронных средств от мощного импульсного электромагнитного излучения известными способами и существующими устройствами. Установлено, что на этапе эксплуатации радиоэлектронных средств основным методом защиты является экранирование. Но наличие технологических отверстий, каналов кабельного ввода, дефектов в корпусах делает невозможной защиту радиоэлектронного устройства от мощного импульсного электромагнитного излучения сверхкороткой длительности. Отмечена необходимость поиска новых технологий, которые позволят уменьшить или полностью исключить проникновение электромагнитного излучения в каскады радиоэлектронных средств. Концепция средств радиоэлектронной защиты на стадии их использования сформулирована на основе природоподобных технологий поглощения, отражения и отвода мощного импульсного электромагнитного излучения за счет использования электроабсорбирующих и запирающих свойств защитного оборудования. Природоподобные технологии имеют преимущество мгновенного отклика состояния электронной подсистемы на воздействие электромагнитного излучения и, соответственно, мгновенного изменения электрофизических свойств твердотельной ионизированной среды. Таким образом, происходит мгновенное изменение отражающих, поглощающих и запирающих свойств защитного оборудования. Кроме того, такие технологии сохраняют свои характеристики на протяжении всего жизненного цикла электронных средств и способны выдерживать импульсные перегрузки.

Ключевые слова: методы защиты от воздействия мощного электромагнитного излучения; радиоэлектронные средства; твердотельная плазменная среда; газообразная плазменная среда; радиоизотопная технология.

\section{Аналіз існуючих методів і пристроїв захисту радіоелектронних засобів від впливу потужного імпульсного електромагнітного випромінювання ультракороткої тривалості}

О. М. Сотніков, М. М. Ясечко, О. Б. Танцюра, О. В. Очкуренко, Д. В. Максюта

Проведено аналіз можливостей реалізації захисту радіоелектронних засобів від потужного імпульсного електромагнітного випромінювання відомими способами i iснуючими пристроями. Встановлено, що на етапі експлуатації радіоелектронних засобів основним методом захисту є екранування. Але наявність технологічних отворів, каналів кабельного вводу, дефектів в корпусах унеможливлює захист радіоелектронного пристрою від потужного імпульсного електромагнітного випромінювання ультракороткої тривалості. Відмічена необхідність пошуку нових технологій, які дозволять зменшити або повністю виключити проникнення електромагнітного випромінювання в каскади радіоелектронних засобів. Концепція засобів радіоелектронного захисту на стадії їх використання сформульована на основі природоподібних технологій поглинання, відбиття і відведення потужного імпульсного електромагнітного випромінювання за рахунок використання електроабсорбуючих і замикаючих властивостей захисного обладнання. Природоподібні технології мають перевагу миттєвого відгуку стану електронної підсистеми на вплив електромагнітного випромінювання i, відповідно, миттєвої зміни електрофізичних властивостей твердотільного іонізованого середовища. Таким чином, відбувається миттєва зміна відбиваючих, поглинаючих і замикаючих властивостей захисного обладнання. Крім того, такі технології зберігають свої характеристики протягом усього життєвого циклу електронних засобів і здатні витримувати імпульсні перевантаження.

Ключові слова: методи захисту від впливу потужного електромагнітного випромінювання; радіоелектронні засоби; твердотільне плазмове середовище; газоподібне плазмове середовище; радіоізотопна технологія. 